\title{
Awake Craniotomy vs Craniotomy Under General Anesthesia for Eloquent Glioma: Postoperative General Functional Preservation
}

Ying-Ching Li

Chang Gung Memorial Hospital https://orcid.org/0000-0001-6789-4211

Hsiao-Yean Chiu

Chang Gung Memorial Hospital

Ya-Jui Lin

Chang Gung Memorial Hospital

Ko-Ting Chen

Chang Gung Memorial Hospital

Peng-Wei Hsu

Chang Gung Memorial Hospital

Yin-Cheng Huang

Chang Gung Memorial Hospital

Pin-Yuan Chen ( $\nabla$ pinyuanc@cgmh.org.tw)

Kuo-Chen Wei

Chang Gung Memorial Hospital

Research article

Keywords: Awake craniotomy, Craniotomy, eloquent area, glioma

Posted Date: October 4th, 2019

DOI: https://doi.org/10.21203/rs.2.15627/v1

License: (1) This work is licensed under a Creative Commons Attribution 4.0 International License.

Read Full License

Version of Record: A version of this preprint was published at Clinical Neurology and Neurosurgery on January 1st, 2021. See the published version at https://doi.org/10.1016/j.clineuro.2020.106343. 


\section{Abstract}

Background Awake craniotomy (AC) with intraoperative stimulation mapping is the standard treatment for glioma, especially when present on the eloquent cortex. The purpose of this study was to investigate whether functional preservation after AC compromises patient survival as compared with craniotomy under general anesthesia (GA).

Methods The medical records of 339 patients who underwent tumor resection surgery for gliomas from January 2010 to December 2014 were retrospectively reviewed. Among these patients, 62 underwent AC with intraoperative stimulation mapping. The primary outcome was the Eastern cooperative oncology group (ECOG) performance score at 3 months postoperatively. Secondary outcomes were the progression-free survival (PFS) and overall survival (OS). A generalized linear model and the Cox proportional hazard model were used to evaluate potential factors influencing general functional status and progression-free survival.

Results The newly-diagnosed disease AC and repeat-surgery groups were comparable in terms of sex, age, pathologic grade, extent of resection (EOR) and preoperative Karnofsky Performance Status (KPS). Among the patients with newly-diagnosed disease, the postoperative ECOG score of the AC group was significantly better than that of the GA group. Pathologic grade and the EOR determined the PFS and OS in both the AC and GA groups.

Conclusion AC with intraoperative stimulation mapping is safe and allows maximal removal of lesions around the eloquent cortex. Greater preservation of neurologic function may have resulted in a better postoperative general functional status in the AC group.

\section{Background}

Achieving maximal surgical resection in patients with a supratentorial glioma has been shown to have a positive effect on progression-free survival (PFS) and overall survival (OS) [1-10]. The most difficult challenge in cases of gliomas located in eloquent regions of the cortex is to find a balance between maximizing tumor resection and avoiding surrounding functional tissues. The traditional method of debulking a tumor from within, which has been used for a long period of time in glioma patients in order to avoid new neurological deficits, is made more difficult in these cases, as evidence has shown that neurologic deficits may occur due to functional tissue being contained inside the tumor $[11,12]$. To overcome this dilemma, awake craniotomy (AC) for surgical mapping of sensorimotor and language functions presents an approach that could be used to attempt to enhance safety and maximize the extent of resection of tumors in eloquent regions of the brain $[13,14]$. By directly stimulating the cortical and subcortical areas that are in proximity to the tumor, $\mathrm{AC}$ allows for identification of functionally-relevant areas of the brain [15]. This technique has enabled removal of tumors from highly-functional eloquent regions that were once considered inoperable [16]. Surgical resection reduces the tumor burden, relieves symptoms caused by the tumor mass effect, and has been proven to be a prognostic factor for survival in 
glioma patients. With improvement in intraoperative techniques and increased surgical experience, intraoperative stimulation mapping, which is performed while the patient remains awake for a short time during brain tumor surgery, is now recognized as a reliable method for use when brain tumors involve eloquent areas (i.e., structures related to sensory, linguistic or motor function). Apparent advantages of intraoperative stimulation mapping in terms of survival in glioma patients were observed from evidence of a maximized extent of resection. Our study aimed to evaluate the experience of one treatment center over 5 years of resection of eloquent gliomas using direct brain stimulation and neuromonitoring, with either AC or surgery under general anesthetic (GA). We compared the extent of resection (EOR) and postoperative functional outcomes between the two methods. This represents the largest comparative study of AC and surgery under GA for the treatment of gliomas located in eloquent motor areas in the literature.

\section{Materials And Methods}

\section{Patient selection}

A list of patients with the diagnosis code ICD-0-3 C71 from 2008 to 2015 was requested from Chang Gung Memorial Hospital Cancer Center. Patients aged over 18 years with a histopathologically-proven malignant brain tumor who underwent treatment at Chang Gung Memorial Hospital, Linkuo Branch, were eligible for this study. Considering that $\mathrm{AC}$ with intraoperative stimulation mapping has been used since 2010 in this treatment center, and the expected survival of WHO grade IV glioblastoma patients is 1.5 years, only patients who underwent surgery from 2010 to 2014 were enrolled for analysis. Patients who underwent a diagnostic biopsy alone, without pathological proof; those under 18 years of age; and those who were followed-up for less than one month were excluded from the analysis. Patient characteristics, treatment course and follow-up status were reviewed via electronic medical records or provided by Chang Gung Memorial Hospital Cancer Center.

\section{Preoperative evaluation}

Preoperative MRI imaging with and without gadolinium was performed within the 2 weeks prior to surgery. Preoperative clinical evaluation, which included a neurological exam, was performed by the surgeon. For the AC patients, baseline language sensorimotor testing was performed and the Karnofsky Performance Status (KPS) was obtained by the AC team in order to determine their suitability for the procedure.

\section{Intraoperative technique}

Anesthesia regimen:The monitored anesthesia care technique was used for sedation for patients undergoing AC. A complete scalp block was applied using 2\% lidocaine with 1:200000 epinephrine. The 
patient was placed in the supine position, and a skull clamp was employed to position the head optimally for surgery.

\section{Tumor volume analysis}

The preoperative tumor volume was determined using T1-weighted MRI with gadolinium contrast for high-grade glioma, or T2-weighted MRI images for low-grade glioma. After surgery, all patients were admitted to the neurosurgical intensive care unit (NSICU). Postoperative MRI was performed within 48 hours to determine the quality of tumor removal. The extent of tumor resection was assessed by a neuroradiologist according to the classification reported by Sawaya et al. [17]: gross total resection (GTR) was achieved if more than $95 \%$ of the tumor was removed; subtotal resection (STR) if $85-95 \%$ was removed; or partial (PR) if $<85 \%$ of the tumor was removed.

\section{Outcome evaluation}

Whether a patient underwent $\mathrm{AC}$ with intraoperative stimulation mapping or conventional craniotomy under GA was determined according to surgical records. The primary outcome was the postoperative ECOG score, which was defined as the general daily performance status score recorded within 7 days after surgery. Secondary outcomes in this study were PFS, which was defined as the duration from diagnosis to either disease progression or the latest follow-up imaging study if no disease progression had been observed, and OS, which was defined as the duration from diagnosis to either death or the latest follow-up. All patients were followed-up to Dec 31, 2016.

\section{Statistical analysis}

The samples were stratified into newly-diagnosed and repeat-surgery groups. In the survival analysis, patients were further divided into groups according to WHO tumor grade (II/III/IV). The Student t test, $X^{2}$ test and Fisher's exact test were used to examine the associations between demographic and clinical factors. Survival curves were estimated by the Kaplan-Meier method. To evaluate the prognostic value of AC with intraoperative stimulation mapping as compared with conventional craniotomy, the log-rank test was adopted. To test whether AC intervention was an independent prognostic factor of PFS and OS, the multivariate Cox proportional hazard model was applied, adjusting for other risk factors. The level of significance was 0.05 , and all tests were performed using SAS software (SAS Institute Inc., Cary, NC).

\section{Study period}

This study was conducted from 1 April, 2016 to 31 March, 2017.

\section{Results}




\section{Baseline characteristics}

Three-hundred and sixty-one tumor resection surgeries performed on 339 glioma patients at Chang Gung Memorial Hospital, Linkou Branch, from 2010 to 2014 were eligible for inclusion in this study. Among the 339 patients, 62 underwent $A C$ with intraoperative stimulation mapping during either an initial surgical intervention or repeat surgery. In the case of a patient undergoing two or more ACs, the first surgical intervention was sampled. Information on initial and repeat surgeries for twenty-two patients in the reference group was obtained. The median follow-up duration in the newly-diagnosed surgery group was 19.2 months (range, 1.2-70.2 months) (Table 1). The mean age of the AC patients in the newlydiagnosed group was 48.6 years, which was slightly younger than the mean of 53.9 years in the GA group $(p=0.0510)$. The age distribution of the patients in the recurrent group was similar to that in the newlydiagnosed group (Table 1). The preoperative KPS demonstrated that the patient populations in the newlydiagnosed group and recurrent group were similar (Table 1).

\section{Tumor characteristics}

A significant difference in WHO grade in the recurrent and the residual glioma patients was observed between the AC group and the reference group $(p=0.0123)$, while no difference between groups was observed when examining the newly-diagnosed glioma patients $(P=0.239)$. Of our overall patient population, more than half had grade IV gliomas, and $53 \%$ and $75 \%$ had a newly-diagnosed glioma and recurrent glioma, respectively. In the AC group, tumors were present in the left hemisphere in $79.5 \%$ and $78.3 \%$ of patients in the newly-diagnosed glioma group and the recurrent glioma group, respectively, greater than the corresponding percentages in the GA group. In the GA group, tumors in the right hemisphere were observed in $46.6 \%$ and $46 \%$ of patients in the newly-diagnosed glioma group and the recurrent glioma group, respectively, greater than the corresponding percentages in the AC group (Table 1).

\section{Postoperative ECOG score}

In the newly-diagnosed disease group, a significantly better postoperative ECOG score was observed in the AC group than in the GA group in this study (ECOG $0-1$ vs $2-4 ; p=0.0098$ ) (Table 1 ). In addition, in the multivariate analysis, $A C$ was demonstrated to be an independent prognostic factor of a better postoperative ECOG score in the newly-diagnosed disease group (Supplementary Table S1).

\section{Extent of resection}

In the newly-diagnosed group, GTR was achieved in 97 (41.1\%) of the GA cases and $19(48.7 \%)$ of the AC cases; STR was observed in $57(24.2 \%)$ of the GA cases and 7 (18\%) of the AC cases, and PR was attained in $82(34.8 \%)$ of the GA cases and $13(33.3 \%)$ of the AC cases. In the newly-diagnosed group, there was no difference in the EOR between the AC group and the GA group. 
In the recurrent group, GTR was achieved in 25 (39.7\%) of the GA cases and 10 (43.5\%) of the AC cases; STR was observed in $8(12.7 \%)$ of the GA cases and $4(17.4 \%)$ of the AC cases, and PR was attained in 30 $(47.6 \%)$ of the GA cases and $9(39.1 \%)$ of the AC cases. In the recurrent group, there was no difference in the EOR between the AC group and the GA group.

\section{Progression-free survival}

No significant difference in PFS was observed between the AC with intraoperative stimulation mapping group and the conventional craniotomy group in all strata of disease status (newly-diagnosed/repeatsurgery) or WHO grade (II/III/IV) (Supplementary Table S2; Fig. 1). Multivariate Cox proportional hazard model analysis revealed that AC was not a prognostic factor of PFS in the glioma patients. The adjusted hazard ratios for newly-diagnosed grade II, grade III and grade IV gliomas were 1.67, 0.99 and 1.54, respectively, and the $95 \%$ confidence intervals all included 1 . The adjusted hazard ratios for repeatsurgery grade II, grade III and grade IV gliomas were $0.28,1.80$ and 0.97 , respectively, and the $95 \%$ confidence intervals all included 1 (Table 2).

\section{Overall survival}

In the newly-diagnosed group, no significant difference in OS was observed between the AC group and the reference group in any WHO grade subgroup (Supplementary Table S3; Fig. 2).The adjusted hazard ratios estimated using the Cox proportional hazard model were $0.76,0.41$ and 0.63 for newly-diagnosed grade II, grade III and grade IV gliomas, respectively, and all 95\% confidence intervals included 1 (Table 3 ).

\section{Subgroup analysis}

One-hundred and sixty-four patients who underwent craniotomies in the left frontal, temporal, or parietal regions were enrolled in the subgroup analysis. In the newly-diagnosed group, patients who underwent AC were of a younger mean age and had a better postoperative ECOG performance status. No significant differences in tumor laterality, tumor number, extent of resection or preoperative KPS were observed between the AC group and the reference group. Survival analyses yielded similar results to those observed for the whole sample. AC with intraoperative stimulation mapping was not associated with PFS, regardless of disease status or WHO grade. After controlling other risk factors (including WHO grade), the adjusted hazard ratios were $1.01(95 \% \mathrm{Cl} 0.57-1.77)$ in the newly-diagnosed group and $0.60(95 \% \mathrm{Cl}$ $0.18-2.01)$ in the repeat-surgery group. In addition, no significant association was observed between AC and OS in the newly-diagnosed group, with an adjusted hazard ratio of 0.99 (95\% $\mathrm{Cl} 0.43-2.28$ ).

\section{Discussion}

Despite advances in functional MRI and neuronavigation techniques that allow anatomic localization of brain function under general anesthesia, real-time feedback regarding the patient's neurological status 
remains a distinct advantage of the AC procedure [18]. Brain mapping during removal of intra-axial tumors enables surgeons to identify a safe corridor to a tumor and facilitates maximum resection with a decreased risk of morbidity $[19,20]$. AC is a practical and effective standard surgical approach for supratentorial intrinsic eloquent area lesions and provides an excellent alternative to craniotomy performed with patients under GA, because it allows the opportunity for brain mapping and avoids the risks associated with GA [21].

\section{Progression-free survival and overall survival}

In our study, no significant differences between the AC and GA groups were observed in either the newlydiagnosed group or the recurrent group. Compared with Sacko et al. [19], with the exception of high-grade gliomas, significant differences were observed between the AC and GA groups in the overall patient population and the low-grade glioma patients; however, it may be the case that a longer follow-up duration is required for low-grade glioma patients owing to their longer average survival duration.

These two major outcomes, to the best of our knowledge, are fully-dependent on the EOR, although many studies have demonstrated benefits of AC, including a lesser risk of neurologic deficit, fewer intraoperative complications, a shorter duration of hospitalization, and a shorter duration of surgery [19, 22 23]. This study may be the first to classify surgical technique and the EOR as two different independent factors related to major outcomes (Table 2), and we found that AC was not a prognostic factor of PFS or OS in glioma patients.

\section{Extent of resection}

In our study, there were no significant differences between the AC group and the GA group, as was also reported by Gupta et al. [22]. In that series, complete resection was achieved in $47.6 \%$ of patients in the AC group, and it was also observed in that study that complete/gross total tumor excision was achieved in a greater number of patients in the GA group (63\%) than in the AC group (47\%). However, in our study, the GTR rate in the AC group was $48.7 \%$ and $43.3 \%$ in the newly-diagnosed patients and repeat-surgery patients, respectively, this result being similar to that reported by Meyer et al., who observed GTR in $52 \%$ of cases [24].Sacko et al. [19] and Eseonu et al. [23] stated that according to statistical analysis, AC can improve the EOR, but it might be the case that different criteria or smaller numbers of patients influenced the results in these two studies. Patients with vascular lesions and metastases were included in the study

by Sacko et al. [19], and there were only 27 patients in the AC group and 31 patients in the GA group in the study by Eseonu et al. [23]. In the present study, only glioma patients were included, and no vascular lesions or metastases were present in the patient population. Sixty-two AC patients were included in this study, and the total patient population numbered 339; all surgeries were carried out in a single treatment center.

\section{Postoperative characteristics}


In our study, significant differences in the postoperative ECOG performance status (classification) were observed between the AC patients and the GA patients in the newly-diagnosed group. Patients in whom mapping successfully identified functional tissue had a higher postoperative ECOG performance status $(86.8 \%)$ than patients with negative brain mapping (64\%), with $p=0.0096$ (Table 1$)$. This may be explained by the fact that although the GTR rate was not significantly elevated in the AC group in our selected study population ( $48.7 \%$ vs. $43.3 \%$ ), this was likely due to better identification of functional cortex boundaries during surgery while the patient remained awake. Thus, it may be that the greater tumor tissue resection in the GA group came at the price of greater functional tissue loss and increased neurological morbidity.

\section{Conclusions}

We have demonstrated that $\mathrm{AC}$ can be performed in cases of perirolandic, eloquent and motor-region glioma, with a better postoperative ECOG score as compared with surgery under GA. However, PFS and OS, which were strongly-dependent on the EOR, did not differ significantly between groups. In this study, we also found that the AC procedure was not an independent prognostic factor of patient survival, in contrast to the EOR. In summary, the benefits of AC for functional preservation are clear, but when it comes to survival rate, the most important prognostic factor is the EOR.

\section{Abbreviations}

AC: Awake craniotomy; GA: General anesthesia; ECOG: Eastern cooperative oncology group;PFS: progression-free survival; OS: overall survival; EOR: extent of resection;KPS: Karnofsky Performance Status; GTR: gross total resection; STR:subtotal resection

\section{Declarations}

\section{Ethics approval and consent to participate}

All procedures performed in studies involving human participants were in accordance with the ethical standards of the institutional or national research committee of Chang Gung Medical Foundation Institutional Review Board, and with the 1964 Helsinki declaration and its later amendments or comparable ethical standards.

\section{Consent for Publication}

The author understands that the Publisher may grant these same rights to Journal. Additionally, the author also grants the right to both Journal and Publisher to enter into agreements with third party entities that grant such third party entities any or all of the rights that author has granted to Publisher herein. The aforementioned rights may include the rights necessary to index and abstract the Submission. 
The author agrees that any subsequent publication of the Submission will credit the Journal as the site of first publication and provide a link to the Journal website.

Author:

Ying-Ching Li

Hsiao-Yean Chiu

Kuo-Chen Wei

Ya-Jui Lin

Ko-Ting Chen

Peng-Wei Hsu

Yin-Cheng Huang

Pin-Yuan Chen

\section{Availability of data and materials}

All data generated or analysed during this study are included in this published article.

\section{Competing interests}

The authors declare to have no personal, financial, or institutional interest in any of the drugs, materials, or devices described in this article. There is no conflict of interest.

\section{Funding}

Not applicable.

\section{Authors' contributions}

Ying-Ching Li: Conception and Design, Statistical analysis, Drafting the Article

Hsiao-Yean Chiu: Statistical analysis

Kuo-Chen Wei: Study supervision

Ya-Jui Lin: Study supervision 
Ko-Ting Chen: Study supervision

Peng-Wei Hsu: Study supervision

Yin-Cheng Huang: Study supervision

Pin-Yuan Chen: Critically Revising the Article, Study supervision

*All authors have read and approved the manuscript

\section{Acknowledgements}

The study was supported by Chang Gung Medical Foundation Grant CMRPG3D0243/CMRPG3G0541

\section{References}

1. Hervey-Jumper SL, Li J, Lau D, Molinaro AM, Perry DW, Meng L, Berger MS (2015) Awake craniotomy to maximize glioma resection: methods and technical nuances over a 27-year period. J Neurosurg 123: 325339 doi:10.3171/2014.10.JNS141520 2. Jakola AS, Myrmel KS, Kloster R, Torp SH, Lindal S, Unsgard G, Solheim $O$ (2012) Comparison of a strategy favoring early surgical resection vs a strategy favoring watchful waiting in low-grade gliomas. JAMA 308: 1881-1888 doi:10.1001/jama.2012.12807 3. Markert JM (2012) The role of early resection vs biopsy in the management of low-grade gliomas. JAMA 308 : 1918-1919 doi:10.1001/jama.2012.14523 4. McGirt MJ, Chaichana KL, Attenello FJ, Weingart JD, Than K, Burger PC, Olivi A, Brem H, Quinones-Hinojosa A (2008) Extent of surgical resection is independently associated with survival in patients with hemispheric infiltrating low-grade gliomas. Neurosurgery 63: 700-707 doi:10.1227/01.NEU.0000325729.41085.73 5. Smith JS, Chang EF, Lamborn KR, Chang SM, Prados MD, Cha S, Tihan T, Vandenberg S, McDermott MW, Berger MS (2008) Role of extent of resection in the long-term outcome of low-grade hemispheric gliomas. J Clin Oncol 26: 1338-1345 doi:10.1200/JC0.2007.13.9337 6. Trimble G, McStravick C, Farling P, Megaw K, McKinstry S, Smyth G, Law G, Courtney H, Quigley G, Flannery T (2015) Awake craniotomy for glioma resection: Technical aspects and initial results in a single institution. Br J Neurosurg 29: 836-842 doi:10.3109/02688697.2015.1054354 7. Almeida JP, Chaichana KL, Rincon-Torroella J, QuinonesHinojosa A (2015) The value of extent of resection of glioblastomas: clinical evidence and current approach. Curr Neurol Neurosci Rep 15: 517 doi:10.1007/s11910-014-0517-x 8. Chaichana KL, JusueTorres I, Lemos AM, Gokaslan A, Cabrera-Aldana EE, Ashary A, Olivi A, Quinones-Hinojosa A (2014) The butterfly effect on glioblastoma: is volumetric extent of resection more effective than biopsy for these tumors? J Neurooncol 120: 625-634 doi:10.1007/s11060-014-1597-9 9. Chaichana KL, Cabrera-Aldana EE, Jusue-Torres I, Wijesekera O, Olivi A, Rahman M, Quinones-Hinojosa A (2014) When gross total resection of a glioblastoma is possible, how much resection should be achieved? World Neurosurg 82: e257-265 doi:10.1016/j.wneu.2014.01.019 10. Chaichana KL, Jusue-Torres I, Navarro-Ramirez R, Raza SM, Pascual-Gallego M, Ibrahim A, Hernandez-Hermann M, Gomez L, Ye X, Weingart JD, Olivi A, Blakeley 
J, Gallia GL, Lim M, Brem H, Quinones-Hinojosa A (2014) Establishing percent resection and residual volume thresholds affecting survival and recurrence for patients with newly diagnosed intracranial glioblastoma. Neuro Oncol 16: 113-122 doi:10.1093/neuonc/not137 11. Skirboll SS, Ojemann GA, Berger MS, Lettich E, Winn HR (1996) Functional cortex and subcortical white matter located within gliomas. Neurosurgery 38: 678-684 12. Ojemann JG, Miller JW, Silbergeld DL (1996) Preserved function in brain invaded by tumor. Neurosurgery 39: 253-258 doi:10.1097/00006123-199608000-00003 13. Walker JA, Quinones-Hinojosa A, Berger MS (2004) Intraoperative speech mapping in 17 bilingual patients undergoing resection of a mass lesion. Neurosurgery 54: 113-117 doi:10.1227/01.neu.0000097270.95721.3b 14. Quiñones-Hinojosa A, Ojemann SG, Sanai N, Dillon WP, Berger MS (2003) Preoperative correlation of intraoperative cortical mapping with magnetic resonance imaging landmarks to predict localization of the Broca area. J Neurosurg 99: 311-318 doi:10.3171/jns.2003.99.2.0311 15. Brown T, Shah AH, Bregy A, Shah NH, Thambuswamy M, Barbarite E, Fuhrman T, Komotar RJ (2013) Awake craniotomy for brain tumor resection: the rule rather than the exception? J Neurosurg Anesthesiol 25: 240-247 doi:10.1097/ANA.0b013e318290c230 16. Boetto J, Bertram L, Moulinie G, Herbet G, Moritz-Gasser S, Duffau H (2015) Low Rate of Intraoperative Seizures During Awake Craniotomy in a Prospective Cohort with 374 Supratentorial Brain Lesions:

Electrocorticography Is Not Mandatory. World Neurosurg 84: 1838-1844 doi:10.1016/j.wneu.2015.07.075 17. Sawaya R, Hammoud M, Schoppa D, Hess KR, Wu SZ, Shi WM, Wildrick DM (1998) Neurosurgical outcomes in a modern series of 400 craniotomies for treatment of parenchymal tumors. Neurosurgery 42: 1044-1055; discussion 1055-1046 doi:10.1097/00006123-199805000-00054 18. Gonen T, Grossman R, Sitt R, Nossek E, Yanaki R, Cagnano E, Korn A, Hayat D, Ram Z (2014) Tumor location and IDH1 mutation may predict intraoperative seizures during awake craniotomy. J Neurosurg 121: 1133-1138 doi:10.3171/2014.7.JNS132657 19. Sacko O, Lauwers-Cances V, Brauge D, Sesay M, Brenner A, Roux FE (2011) Awake craniotomy vs surgery under general anesthesia for resection of supratentorial lesions. Neurosurgery 68: 1192-1198; discussion 1198-1199 doi:10.1227/NEU.0b013e31820c02a3 20. Ebeling U, Schmid UD, Ying H, Reulen HJ (1992) Safe surgery of lesions near the motor cortex using intra-operative mapping techniques: a report on 50 patients. Acta Neurochir (Wien) 119: 23-28 21. Nossek E, Matot I, Shahar T, Barzilai O, Rapoport Y, Gonen T, Sela G, Grossman R, Korn A, Hayat D, Ram Z (2013) Intraoperative seizures during awake craniotomy: incidence and consequences: analysis of 477 patients. Neurosurgery 73: 135-140 doi:10.1227/01.neu.0000429847.91707.97 22. Gupta DK, Chandra PS, Ojha BK, Sharma BS, Mahapatra AK, Mehta VS (2007) Awake craniotomy versus surgery under general anesthesia for resection of intrinsic lesions of eloquent cortex-a prospective randomised study. Clin Neurol Neurosurg 109: 335-343 doi:10.1016/j.clineuro.2007.01.008 23. Eseonu Cl, Rincon-Torroella J, ReFaey K, Lee YM, Nangiana J, Vivas-Buitrago T, Quinones-Hinojosa A (2017) Awake Craniotomy vs Craniotomy Under General Anesthesia for Perirolandic Gliomas: Evaluating Perioperative Complications and Extent of Resection. Neurosurgery 81: 481-489 doi:10.1093/neuros/nyx023 24. Meyer FB, Bates LM, Goerss SJ, Friedman JA, Windschitl WL, Duffy JR, Perkins WJ, O'Neill BP (2001) Awake craniotomy for aggressive resection of primary gliomas located in eloquent brain. Mayo Clin Proc 76: 677-687 doi:10.4065/76.7.677 


\section{Tables}

Table 1 Baseline characteristics of the patients in the awake craniotomy and reference groups.

\begin{tabular}{|c|c|c|c|c|c|c|}
\hline \multirow[t]{2}{*}{ Characteristics, n (\%) } & \multicolumn{3}{|c|}{ Newly-diagnosed disease } & \multicolumn{3}{|c|}{ Residual or recurrent disease } \\
\hline & $\begin{array}{l}\text { Reference* } \\
(\mathrm{n}=236)\end{array}$ & $\begin{array}{c}\text { Awake } \\
\text { craniotomy (n } \\
=39)\end{array}$ & $\mathrm{p}$ & $\begin{array}{l}\text { Reference* } \\
\quad(n=63)\end{array}$ & $\begin{array}{c}\text { Awake } \\
\text { craniotomy } \\
(\mathrm{n}=23)\end{array}$ & $\mathrm{p}$ \\
\hline Disease status & & & N/A & & & $\mathrm{N} / \mathrm{A}$ \\
\hline Newly-diagnosed & $236(100.0)$ & 39 (100.0) & & $0(0.0)$ & $0(0.0)$ & \\
\hline Residual & $0(0.0)$ & $0(0.0)$ & & $4(6.3)$ & $3(13.0)$ & \\
\hline Recurrent & $0(0.0)$ & $0(0.0)$ & & $59(93.7)$ & $20(87.0)$ & \\
\hline $\begin{array}{l}\text { Age at surgery, years, mean } \\
\text { (SD) }\end{array}$ & $53.9(15.6)$ & $48.6(14.7)$ & 0.0510 & $52.4(13.6)$ & $47.1(12.2)$ & 0.1037 \\
\hline Gender & & & 0.6227 & & & 0.0169 \\
\hline Female & 99 (41.9) & $18(46.1)$ & & $18(28.6)$ & $13(56.5)$ & \\
\hline Male & $137(58.1)$ & $21(53.9)$ & & $45(71.4)$ & $10(43.5)$ & \\
\hline WHO grade & & & 0.2390 & & & 0.0123 \\
\hline II & $57(24.2)$ & $12(30.8)$ & & $6(9.5)$ & $8(34.8)$ & \\
\hline II & $48(20.3)$ & $11(28.2)$ & & $15(23.8)$ & $6(26.1)$ & \\
\hline IV & $131(55.5)$ & $16(41.0)$ & & $42(66.7)$ & $9(39.1)$ & \\
\hline Laterality (classification) & & & $<0.0001$ & & & $<0.0001$ \\
\hline $\begin{array}{l}\text { Bilateral/midline } \\
\text { involvement }\end{array}$ & $51(21.6)$ & $7(18.0)$ & & $22(34.9)$ & $3(13.0)$ & \\
\hline Left & 75 (31.8) & 31 (79.5) & & $12(19.1)$ & 18 (78.3) & \\
\hline Right & $110(46.6)$ & $1(2.6)$ & & $29(46.0)$ & $2(8.7)$ & \\
\hline Extent of resection & & & 0.5966 & & & 0.7433 \\
\hline Gross-near total & $97(41.1)$ & $19(48.7)$ & & $25(39.7)$ & $10(43.5)$ & \\
\hline Subtotal & $57(24.2)$ & $7(18.0)$ & & $8(12.7)$ & $4(17.4)$ & \\
\hline Partial & $82(34.8)$ & $13(33.3)$ & & $30(47.6)$ & $9(39.1)$ & \\
\hline $\begin{array}{l}\text { Preoperative Karnofsky } \\
\text { performance status } \\
\text { (classification) }\end{array}$ & & & 0.5463 & & & 0.1388 \\
\hline $100-80$ & $180(76.3)$ & $28(71.8)$ & & $36(57.1)$ & $9(39.1)$ & \\
\hline 70 or less & $56(23.7)$ & $11(28.2)$ & & 27 (42.9) & $14(60.9)$ & \\
\hline $\begin{array}{l}\text { Postoperative ECOG } \\
\text { performance status } \\
\text { (classification) }\end{array}$ & & & 0.0098 & & & 0.3674 \\
\hline $0-1$ & $150(63.6)$ & $33(84.6)$ & & $26(41.3)$ & $12(52.2)$ & \\
\hline $2-4$ & $86(36.4)$ & $6(15.4)$ & & $37(58.7)$ & $11(47.8)$ & \\
\hline
\end{tabular}

Table 2 Multivariate analysis: awake craniotomy $\rightarrow$ PFS, according to the multivariate Cox proportional hazard model, stratified by disease status and WHO grade. 


\begin{tabular}{|c|c|c|c|c|c|c|}
\hline \multirow[t]{2}{*}{ Covariate } & \multicolumn{2}{|c|}{$\begin{array}{l}\text { Grade II glioma }(\mathrm{n}= \\
67)\end{array}$} & \multicolumn{2}{|c|}{$\begin{array}{l}\text { Grade III glioma }(\mathrm{n}= \\
\text { 58) }\end{array}$} & \multicolumn{2}{|c|}{$\begin{array}{l}\text { Grade IV glioma } \\
(\mathrm{n}=140)\end{array}$} \\
\hline & $\begin{array}{l}\mathrm{P} \\
\text { value }\end{array}$ & $\begin{array}{l}\text { Hazard ratio } \\
(95 \% \mathrm{CI})\end{array}$ & $\begin{array}{l}\mathrm{P} \\
\text { value }\end{array}$ & $\begin{array}{l}\text { Hazard ratio } \\
(95 \% \mathrm{CI})\end{array}$ & $P$ value & $\begin{array}{l}\text { Hazard } \\
\text { ratio } \\
(95 \% \\
\text { CI) } \\
\end{array}$ \\
\hline \multicolumn{7}{|l|}{ Newly-diagnosed disease } \\
\hline Awake craniotomy, yes & 0.4131 & $\begin{array}{l}1.669(0.490- \\
5.687)\end{array}$ & 0.9931 & $\begin{array}{l}0.995(0.317- \\
3.122)\end{array}$ & 0.2112 & $\begin{array}{l}1.537 \\
(0.784- \\
3.016)\end{array}$ \\
\hline Age, per 10 increase & 0.4446 & $\begin{array}{l}1.192(0.760- \\
1.869)\end{array}$ & 0.1133 & $\begin{array}{l}1.246(0.949- \\
1.636)\end{array}$ & 0.0014 & $\begin{array}{l}1.307 \\
(1.109- \\
1.541)\end{array}$ \\
\hline Gender, male vs. female & 0.0002 & $\begin{array}{l}9.198(2.886- \\
29.317)\end{array}$ & 0.4452 & $\begin{array}{l}1.324(0.644- \\
2.723)\end{array}$ & 0.7989 & $\begin{array}{l}0.944 \\
(0.608- \\
1.467)\end{array}$ \\
\hline $\begin{array}{l}\text { Preoperative KPS, } \\
\leq 70 \text { vs. } 80-100\end{array}$ & 0.0468 & $\begin{array}{l}0.251(0.064- \\
0.981)\end{array}$ & 0.7176 & $\begin{array}{l}0.847(0.346- \\
2.078)\end{array}$ & 0.2178 & $\begin{array}{l}0.743 \\
(0.464- \\
1.191)\end{array}$ \\
\hline $\begin{array}{l}\text { Postoperative ECOG } \\
\text { PS, } 2-4 \text { vs. } 0-1\end{array}$ & 0.0004 & $\begin{array}{l}12.517 \\
(3.083- \\
50.811)\end{array}$ & 0.7952 & $\begin{array}{l}1.129(0.452- \\
2.819)\end{array}$ & 0.6474 & $\begin{array}{l}1.114 \\
(0.701- \\
1.773)\end{array}$ \\
\hline Laterality, right vs. left & 0.0512 & $\begin{array}{l}2.778(0.995- \\
7.756)\end{array}$ & 0.5890 & $\begin{array}{l}1.296(0.506- \\
3.324)\end{array}$ & 0.0971 & $\begin{array}{l}1.531 \\
(0.926- \\
2.533)\end{array}$ \\
\hline $\begin{array}{l}\text { Laterality, bilateral/midline } \\
\text { involvement vs. left }\end{array}$ & 0.3529 & $\begin{array}{l}1.625(0.583- \\
4.528)\end{array}$ & 0.6569 & $\begin{array}{l}1.290(0.420- \\
3.961)\end{array}$ & 0.0050 & $\begin{array}{l}2.306 \\
(1.287- \\
4.131)\end{array}$ \\
\hline $\begin{array}{l}\text { Extent of resection, near } \\
\text { total/subtotal vs. gross total }\end{array}$ & 0.1549 & $\begin{array}{l}2.478(0.710- \\
8.654)\end{array}$ & 0.1269 & $\begin{array}{l}2.484(0.772- \\
7.986)\end{array}$ & $<0.0001$ & $\begin{array}{l}2.959 \\
(1.804- \\
4.854)\end{array}$ \\
\hline $\begin{array}{l}\text { Extent of resection, partial vs. } \\
\text { gross total }\end{array}$ & 0.1106 & $\begin{array}{l}2.904(0.784- \\
10.757)\end{array}$ & 0.0222 & $\begin{array}{l}3.743(1.207- \\
11.607)\end{array}$ & $<0.0001$ & $\begin{array}{l}3.364 \\
(1.882- \\
6.011) \\
\end{array}$ \\
\hline \multicolumn{7}{|l|}{ Residual/recurrent disease } \\
\hline Awake craniotomy, yes & 0.6080 & $\begin{array}{l}0.430(0.017- \\
10.792)\end{array}$ & 0.0384 & $\begin{array}{l}13.746 \\
(1.151- \\
164.176)\end{array}$ & 0.4898 & $\begin{array}{l}0.580 \\
(0.123- \\
2.723)\end{array}$ \\
\hline Age, per 10 increase & 0.5457 & $\begin{array}{l}1.962(0.220- \\
17.465)\end{array}$ & 0.4399 & $\begin{array}{l}0.754(0.368- \\
1.543)\end{array}$ & 0.4977 & $\begin{array}{l}1.143 \\
(0.777\end{array}$ \\
\hline
\end{tabular}




\begin{tabular}{|c|c|c|c|c|c|c|}
\hline & & & & & & 1.682) \\
\hline Gender, male vs. female & 0.7384 & $\begin{array}{l}1.892(0.045- \\
79.643)\end{array}$ & 0.9455 & $\begin{array}{l}1.175(0.021- \\
120.081)\end{array}$ & 0.0144 & $\begin{array}{l}0.349 \\
(0.150- \\
0.811)\end{array}$ \\
\hline Preoperative KPS, $\leq 70$ vs. $80-100$ & 0.5991 & $\begin{array}{l}6.942(0.005- \\
9523.172)\end{array}$ & 0.0524 & $\begin{array}{l}0.031(0.001- \\
1.037)\end{array}$ & 0.5565 & $\begin{array}{l}0.735 \\
(0.264- \\
2.048)\end{array}$ \\
\hline $\begin{array}{l}\text { Postoperative ECOG PS, 2-4 vs. } \\
0-1\end{array}$ & 0.7690 & $\begin{array}{l}0.611(0.023- \\
16.351)\end{array}$ & 0.0129 & $\begin{array}{l}141.325 \\
(2.857- \\
6991.877)\end{array}$ & 0.4348 & $\begin{array}{l}1.504 \\
(0.540- \\
4.192)\end{array}$ \\
\hline Laterality, right vs. left & 0.5843 & $\begin{array}{l}2.346(0.111- \\
49.743)\end{array}$ & 0.0106 & $\begin{array}{l}104.249 \\
(2.960- \\
3671.331)\end{array}$ & 0.4185 & $\begin{array}{l}0.571 \\
(0.147- \\
2.217)\end{array}$ \\
\hline $\begin{array}{l}\text { Laterality, bilateral/midline } \\
\text { involvement vs. left }\end{array}$ & $\mathrm{N} / \mathrm{A}$ & $\mathrm{N} / \mathrm{A}$ & 0.3659 & $\begin{array}{l}5.282(0.143- \\
194.732)\end{array}$ & 0.5080 & $\begin{array}{l}0.642 \\
(0.172- \\
2.389)\end{array}$ \\
\hline $\begin{array}{l}\text { Extent of resection, near } \\
\text { total/subtotal vs. gross total }\end{array}$ & 0.7787 & $\begin{array}{l}2.635(0.003- \\
2271.344)\end{array}$ & 0.1268 & $\begin{array}{l}4.739(0.643- \\
34.921)\end{array}$ & 0.8830 & $\begin{array}{l}0.926 \\
(0.332- \\
2.580)\end{array}$ \\
\hline $\begin{array}{l}\text { Extent of resection, partial vs. } \\
\text { gross total }\end{array}$ & 0.1763 & $\begin{array}{l}9.244(0.368- \\
232.203)\end{array}$ & 0.0804 & $\begin{array}{l}14.460 \\
(0.724- \\
288.769)\end{array}$ & 0.3893 & $\begin{array}{l}1.664 \\
(0.522- \\
5.307)\end{array}$ \\
\hline
\end{tabular}

Note: Missing PFS information in newly-diagnosed disease: grade II = 2, grade III = 1, grade IV = 7; Missing PFS information in residual/recurrent disease: grade III $=2$, grade IV $=6$.

Table 3 Multivariate analysis: awake craniotomy $\rightarrow$ overall survival, according to the multivariate Cox proportional hazard model, stratified by disease status and WHO grade. 


\begin{tabular}{|c|c|c|c|c|c|c|}
\hline \multirow[t]{2}{*}{ Covariate } & \multicolumn{2}{|c|}{$\begin{array}{l}\text { Grade II glioma }(\mathrm{n}= \\
69)\end{array}$} & \multicolumn{2}{|c|}{$\begin{array}{l}\text { Grade III glioma }(\mathrm{n}= \\
59)\end{array}$} & \multicolumn{2}{|c|}{$\begin{array}{l}\text { Grade IV glioma } \\
(\mathrm{n}=147)\end{array}$} \\
\hline & $\begin{array}{l}\mathrm{P} \\
\text { value }\end{array}$ & $\begin{array}{l}\text { Hazard ratio } \\
(95 \% \mathrm{CI})\end{array}$ & $\begin{array}{l}\mathrm{P} \\
\text { value }\end{array}$ & $\begin{array}{l}\text { Hazard } \\
\text { ratio (95\% } \\
\text { CI) }\end{array}$ & $\begin{array}{l}\mathrm{P} \\
\text { value }\end{array}$ & $\begin{array}{l}\text { Hazard } \\
\text { ratio } \\
(95 \% \\
\text { CI })\end{array}$ \\
\hline \multicolumn{7}{|l|}{ Newly-diagnosed disease } \\
\hline Awake craniotomy, yes vs. no & 0.8206 & $\begin{array}{l}0.759(0.070- \\
8.196)\end{array}$ & 0.4441 & $\begin{array}{l}0.411 \\
(0.042- \\
4.002)\end{array}$ & 0.6317 & $\begin{array}{l}0.807 \\
(0.336- \\
1.940)\end{array}$ \\
\hline Age, per 10 increase & 0.6535 & $\begin{array}{l}1.180(0.573- \\
2.430)\end{array}$ & 0.7886 & $\begin{array}{l}1.062 \\
(0.686- \\
1.642)\end{array}$ & 0.0008 & $\begin{array}{l}1.419 \\
(1.157- \\
1.740)\end{array}$ \\
\hline Gender, male vs. female & 0.4739 & $\begin{array}{l}2.006(0.298- \\
13.492)\end{array}$ & 0.3970 & $\begin{array}{l}1.710 \\
(0.494- \\
5.922)\end{array}$ & 0.9818 & $\begin{array}{l}1.006 \\
(0.619- \\
1.635)\end{array}$ \\
\hline Preoperative KPS, $\leq 70$ vs. $80-100$ & 0.6293 & $\begin{array}{l}0.509(0.033- \\
7.885)\end{array}$ & 0.6696 & $\begin{array}{l}0.700 \\
(0.136- \\
3.600)\end{array}$ & 0.4902 & $\begin{array}{l}1.203 \\
(0.712- \\
2.031)\end{array}$ \\
\hline $\begin{array}{l}\text { Postoperative ECOG PS, } 2-4 \text { vs. } 0- \\
1\end{array}$ & 0.0719 & $\begin{array}{l}5.912(0.854- \\
40.950)\end{array}$ & 0.4530 & $\begin{array}{l}1.646 \\
(0.448- \\
6.048)\end{array}$ & 0.0477 & $\begin{array}{l}1.674 \\
(1.005- \\
2.788)\end{array}$ \\
\hline Laterality, right vs. left & 0.8136 & $\begin{array}{l}1.210(0.249- \\
5.885)\end{array}$ & 0.8339 & $\begin{array}{l}1.152 \\
(0.307- \\
4.325)\end{array}$ & 0.7024 & $\begin{array}{l}1.117 \\
(0.633- \\
1.970)\end{array}$ \\
\hline $\begin{array}{l}\text { Laterality, bilateral/midline } \\
\text { involvement vs. left }\end{array}$ & 0.3011 & $\begin{array}{l}0.381(0.061- \\
2.374)\end{array}$ & 0.8055 & $\begin{array}{l}0.806 \\
(0.144- \\
4.504)\end{array}$ & 0.0143 & $\begin{array}{l}2.301 \\
(1.181- \\
4.483)\end{array}$ \\
\hline $\begin{array}{l}\text { Extent of resection, near } \\
\text { total/subtotal vs. gross total }\end{array}$ & 0.9941 & N/A & 0.2331 & $\begin{array}{l}3.985 \\
(0.411- \\
38.672)\end{array}$ & 0.0016 & $\begin{array}{l}2.685 \\
(1.453- \\
4.960)\end{array}$ \\
\hline $\begin{array}{l}\text { Extent of resection, partial vs. } \\
\text { gross total }\end{array}$ & 0.9937 & $\mathrm{~N} / \mathrm{A}$ & 0.0885 & $\begin{array}{l}7.029 \\
(0.745- \\
66.288)\end{array}$ & 0.0042 & $\begin{array}{l}2.722 \\
(1.372- \\
5.400)\end{array}$ \\
\hline
\end{tabular}

\section{Figures}



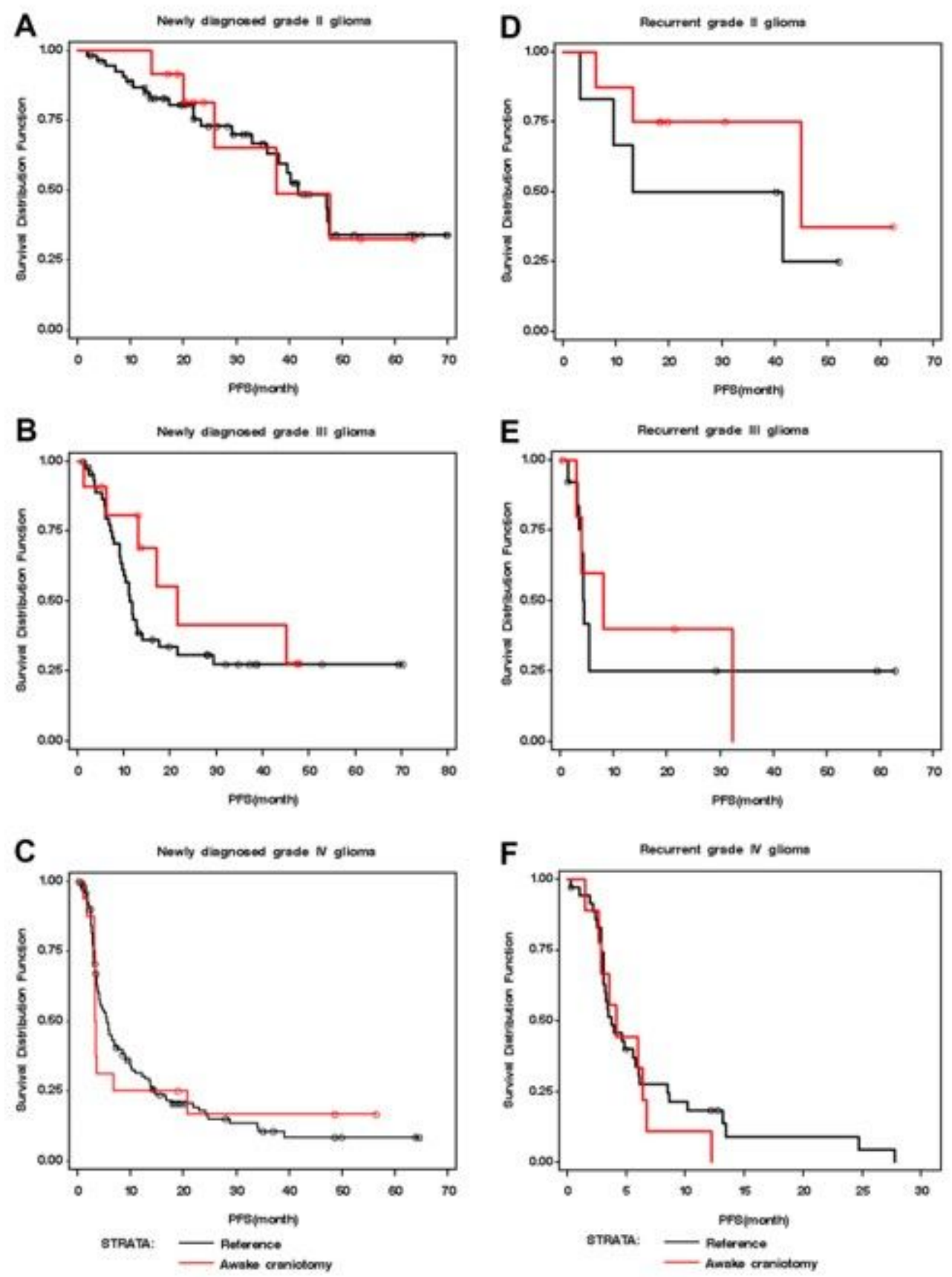

\section{Figure 1}

Progression-free survival (PFS) in newly-diagnosed patients: (A) Grade II, (B) Grade III, (C) Grade IV; and PFS in repeat-surgery patients: (D) Grade II, (E) Grade III, (F) Grade IV. 

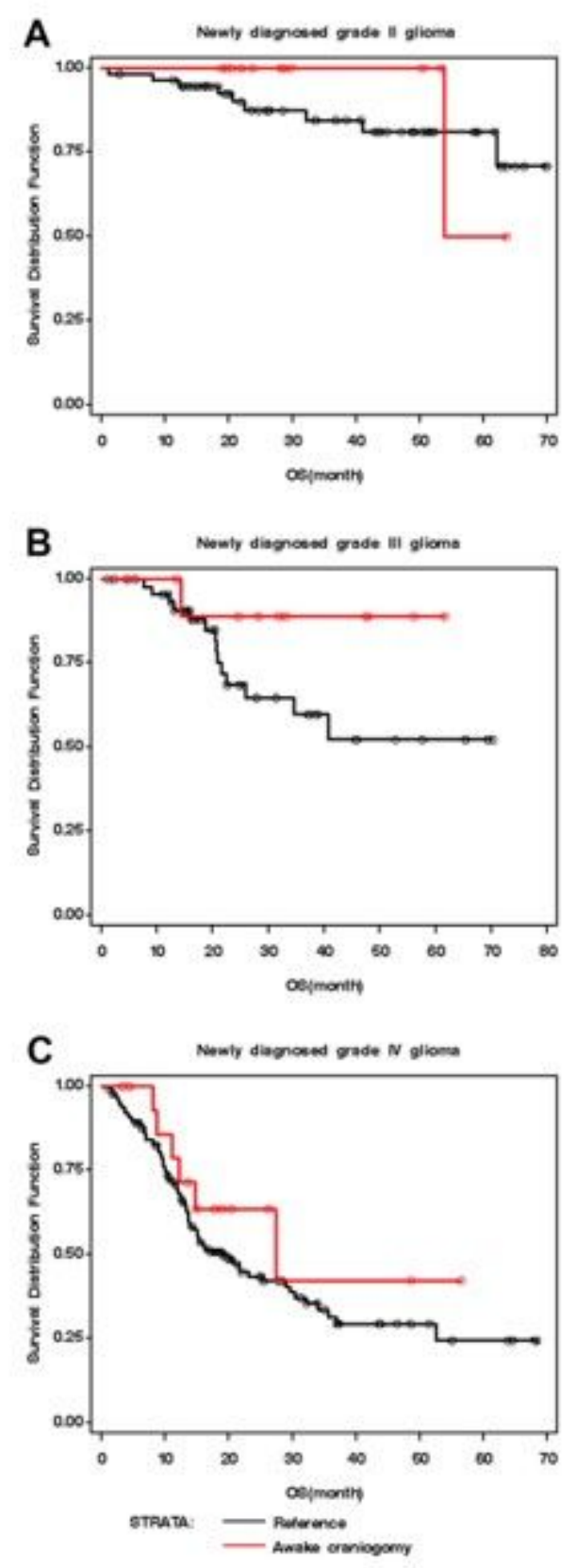

Figure 2

Overall survival (OS) in newly-diagnosed patients. (A) Grade II, (B) Grade III, (C) Grade IV. 